\author{
International Journal of Sustainable Energy and Environmental \\ Research \\ 2021 Vol. 10, No. 2, pp. 101-113. \\ $\operatorname{ISSN}(e): 2306-6253$ \\ $\operatorname{ISSN}(p): 2312-5764$ \\ DOI: 10.18488/journal.13.2021.102.101.113 \\ (C) 2021 Conscientia Beam. All Rights Reserved. \\ check for \\ updates
}

\title{
SOLAR POWER ANALYSIS UNDER VARYING ENVIRONMENTAL CONDITION USING SOLAR EMULATOR
}

Anjali Garg

\author{
Associate Prof., Department of Electrical, Electronics and Communication \\ Engineering, The NorthCap University, Gurugram, Haryana, India. \\ Email:anjalineerajgarg867@gmail.com Tel:09871370985
}

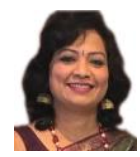

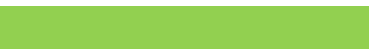

Article History

Received: 7 October 2021 Revised: 10 November 2021 Accepted: 3 December 2091 Published: 28 December 2021

\section{Keywords}

PV emulator

$\mathrm{I}-\mathrm{V}$

P-V characteristics

Photovoltaic module

Partial shading

Hardware implementation controller.

\section{$A B S T R A C T$}

The current situation of fast depleting non-renewable resources and excessive damage done to mother earth due to severe mechanization and industrialization has resulted in alarming rate of pollutions. The one-word answer for it is that we should start harnessing renewable resources of energy. Tapping sun's energy is a wonderful and apt answer to the current situation of energy requirement. World over this technology is worked upon to make use of sun's energy easy to be converted into usable energy form i.e. electricity. The research work being carried on in varied fields however to mention one such aspect of solar panels is irradiance -receiving and capturing powers. Along with the irradiance, the area of a panel which is exposed to sun, the daytime and location are some of the factors affecting the amount of power generated using solar power as generating source. From research point of view, to analyze the effect of variation of these parameters, it is difficult to get the analysis data using solar panels and hence now a day's emulator is preferred and used for research purposes. This paper focuses on the basics of emulator, its structure, functioning, effect of various parameter variations on the analysis of the generated power and other related benefits using emulator. The paper also presents the effect of partial shading on the maximum power generated and the efficiency hence obtained. The performance analysis is done on an Experimental set up fabricated in Research lab.

Contribution/Originality: This paper contributes to the existing literature by presenting the effect of various parameter variations on the analysis of the generated power using solar power and related benefits using emulators. The performance analysis presented in the paper is done on an Experimental set up fabricated in the Research lab funded by DST, Delhi, India.

\section{INTRODUCTION}

Nowadays, with increasing exploitation of non-renewable energy resources, the world needs to focus more on renewable energy resources. Among all kinds of renewable energy resources, PV Solar energy is considered to be the most effective and sustainable one because of the abundance of solar radiant energy (Chiang, Chang, \& Yen, 1998). Solar energy resource is one of the leading renewable resources helping worldwide to deal with energy and power generation crisis in both public as well as the private sector (Babu, Ram, Sangeetha, Laudani, \& Rajasekar, 2016; Nishioka, Sakitani, Uraoka, \& Fuyuki, 2007). The Worldwide growth of solar photovoltaic is extremely dynamic and varies strongly as per country. Global Solar PV is estimated to grow significantly from $494.3 \mathrm{GW}$ in 2018 to 1582.9 GW in 2030 (Al-Shetwi, Sujod, \& Ramli, 2015). 
The limitation for analysis of the photovoltaic system is not only that it requires large space as well as expensive installation of PV Panels but also varying environmental conditions (day, night, cloudy, rainy, etc.). To overcome these limitations PV emulator has been proposed to simulate the better performance of a photovoltaic system which can evaluate the performance in the laboratory at any time and also not reliant on any actual photovoltaic panel (Zhou, Holland, \& Igic, 2014). The PV Emulator helps to emulate I-V (Current-voltage) curve and P-V (power voltage) curves of a solar cell (privileged by external conditions such as solar irradiance, temperature, and relative humidity) which is required for analysis purposes (Ebrahim, Ahmed, Elmasry, \& Mohammed, 2015). PV emulator architecture comprises of three major sections: PV model implementation, control strategy, and power stage control (Ayop \& Tan, 2017) which are discussed in detail in paper further.

\section{NEED OF PV EMULATOR}

Installation of an actual photovoltaic system for laboratory testing proves to be very costly and there is a change in climatic conditions, atmospheric conditions that cannot help in getting desired outputs (Shahabuddin et al., 2018). Therefore, a system is required which can emulate similar results of PV panel by varying different parameters necessary to get the desired output (Ayop \& Tan, 2017). PV Emulators comprising of switching mode power supplies are highly recommended for high power applications. These are usually known for their high efficiency and fast dynamic response. It comprises of linear power supplies which comes into picture when there is low power control and also less complexity is required (Vagapov \& Alecksey, 2016). Conventionally, controls of PV Emulators were usually digital (DSP Boards) but nowadays PV Emulators are PC controlled using a proprietary software like LabVIEW, DSPACE, PyLab works, MATLAB Simulink etc. These softwares provide an environment for better understanding of non-linearity of I-V / P-V Graphs, manually adjusting various parameters and easy extraction of experimental values (Vlad et al., 2017). PV Emulator simulates the I-V curve and the P-V curve under varying environmental conditions. It tests and verifies different parameters of a Photovoltaic system like efficiency, fill-factor etc.

\section{SYSTEM DESCRIPTION}

Figures 1 (a) and Figure 1 (b) is a connection diagram and block diagram representation of the proposed system with DC Programmable supply-based PV Emulator consisting of a PC installed with proprietary software (soft panel) connected with controller (SPVEO01). The controller is bi- directionally connected to convertor which is further connected to load to give the desired output (Moussa, Khedher, \& Bouallegue, 2019).



Figure-1(a). Connection diagram of the proposed system. 


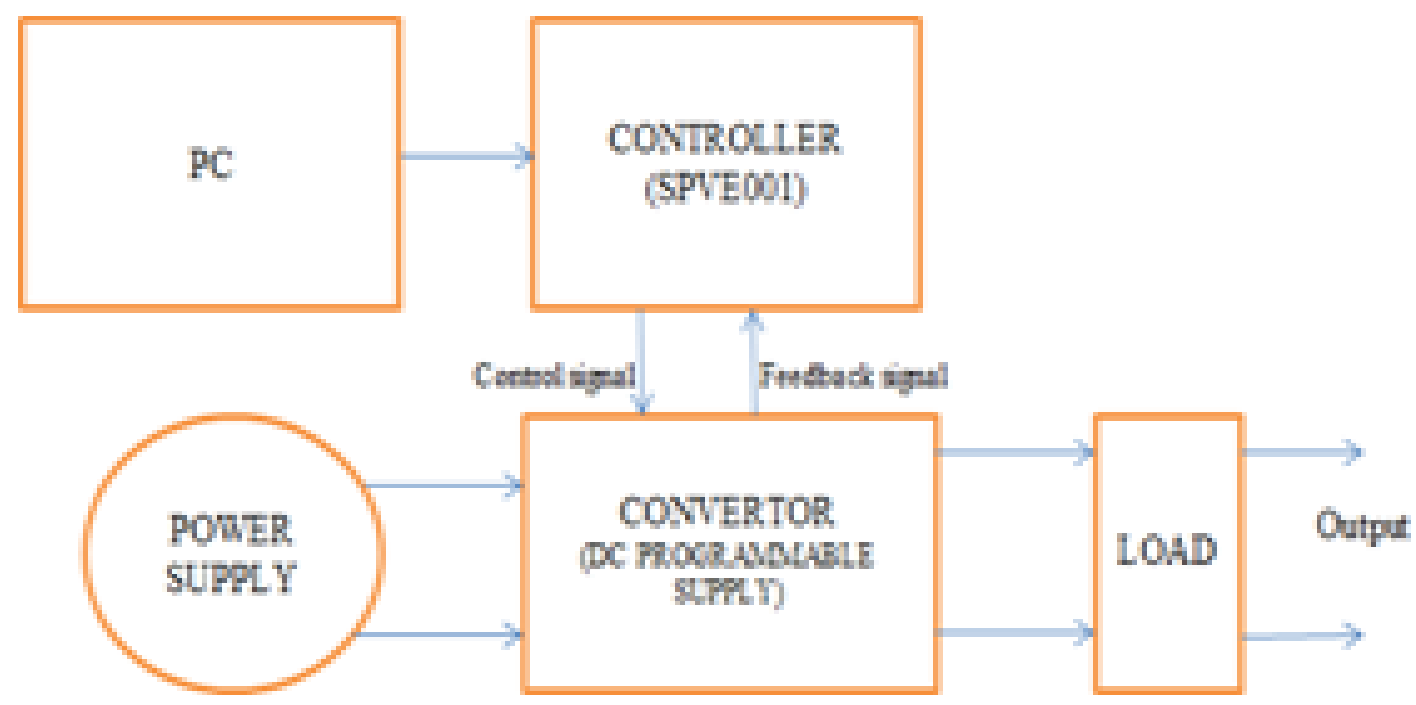

Figure-1(b). Block Diagram of proposed system with DC Programmable supply-based PV Emulator (Ebrahim et al., 2015).

Figure 2 is a general Structure of the proposed PV Emulator Controller section shown with respect to Figure 1. In this, different parameters are varied which when compiled with the controller, generates a control signal and transfers to the DC Programmable supply. A DC-DC converter as shown in Figure 1 is an important part of a PV emulator based on converter logic. Thus, converter generates output voltage and output current, sends feedback to the controller, and generate output I-V and P-V curve and display them on PC (Shahabuddin et al., 2018).

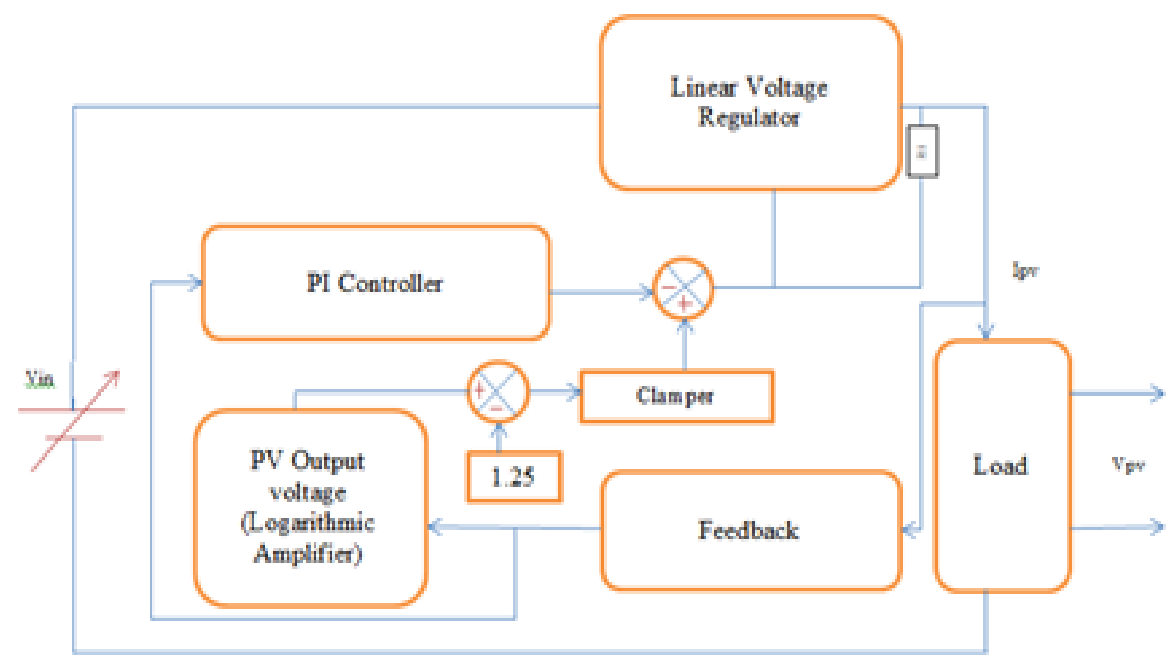

Figure-2. General Structure of PV Emulator Controller (Moussa et al., 2019).

\subsection{Curve Analysis of a PV Module}

The I-V curve as shown in Figure 3 is a graphical representation of the feasible working spots of a photovoltaic module when tested under conditions like solar radiation, temperature, and partial shading. There are a few variables that need to be understood for having a clear idea of the current-voltage graph: -

- $\mathrm{V}_{\mathrm{oc}}=$ open-circuit voltage- That's the point on the I-V curve, where the PV module will work if we attach a very high or near-infinite resistance load. It is the point with the maximum voltage with no current. The Voc varies with changes in irradiance but not so much as compared to Isc. Voc changes logarithmically with the light intensity.

- $\quad \mathrm{I}_{\mathrm{sc}}=$ short-circuit current - It is a point on the I-V curve where the PV module works if a zero-resistance load or near zero resistance load is applied to the PV device. It is the point with the maximum current with no 
voltage. It varies linearly with the incident radiation. Therefore, whenever there is a change in the incident radiation, there is a corresponding change in the Isc.

- $\quad \mathrm{MPP}=$ maximum power point - The point on the curve where the product of the voltage and the current is maximum is called the maximum power point and it is basically on the knee of the curve. This point is basically of interest to all end users of PV. It represents the actual power that can be extracted from a PV device when varied under different environmental conditions. The voltage at this point is Vmpp and current at this point is Impp (Messaoudi, Bennani, Bellaaj, \& Orabi, 2016).

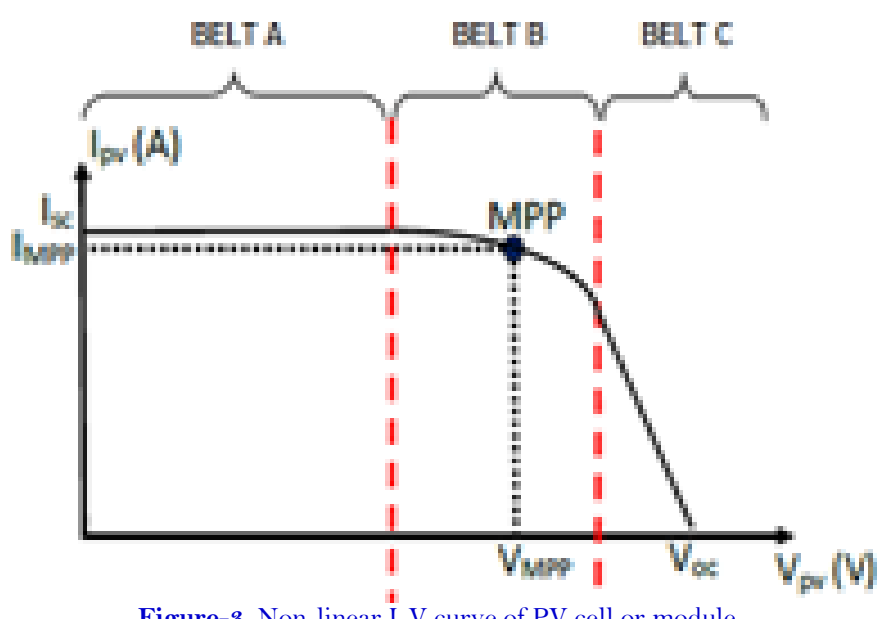

The I-V curve as shown in Figure 3 can be disintegrated into three belts: -

- Belt A where the PV module acts as a current producer.

- Belt $\mathrm{B}$ is an intermediary belt that includes the MPP.

- Belt $\mathrm{C}$ where the PV module generates the voltage.

The above-stated variables are calculated by using the Equations 1 to 4 given below:

$$
\begin{aligned}
& I_{a c}=I_{a c} \cdot \frac{G}{G_{s d}}\left(1+a\left(T-T_{a d}\right)\right) \\
& I_{m p p p}=I_{m p p p} \cdot \frac{G}{G_{x d}}\left(1+a\left(T-T_{g d}\right)\right) \\
& V_{\text {out }}=V_{o c} \cdot\left(1+b\left(G-G_{g d}\right)\right)\left(1-c\left(T-T_{g d}\right)\right) \\
& V_{m p p}=V_{m p p} \cdot\left(1+b\left(G-G_{g d}\right)\right)\left(1-c\left(T-T_{g d}\right)\right)
\end{aligned}
$$

Where $G$ is the irradiance, $T$ is the temperature, $V_{\text {mpp }}$ and $I_{m p p}$ are the voltage and current at maximum power point respectively, a is the temperature coefficient of Isc, $\mathrm{b}$ is the temperature coefficient of $\mathrm{V}_{\mathrm{oc}}, \mathrm{c}$ is the coefficient showing the power deviation in the function of the panel temperature.

The value of these variables is acquired in standard climatic conditions $\left(T_{\mathrm{sd}}=25^{\circ} \mathrm{C}, \mathrm{G}_{\mathrm{sd}}=1000 \mathrm{~W} / \mathrm{m}^{2}\right)$ where

$\mathrm{T}_{\mathrm{sd}}$ and Gsd are temperature and irradiance at standard test conditions (STC) respectively and the values of $\mathrm{V}_{\mathrm{oc}} *, \mathrm{I}_{\mathrm{sc}} *, \mathrm{~V}_{\mathrm{mpp}} *, \mathrm{I}_{\mathrm{mpp}} *$ are given by the manufacturer of the PV module.

The PV current $l_{\text {PV }}$ as shown in Figure 2 can be expressed as a function of $T$ and $G$, and PV voltage $V P V$ can be expressed as a function of $T, G$, and $I P V$. The proposed PV emulator is designed by using analog circuits, which are 
constructed around operational amplifiers, logarithmic amplifier, variable resistors, adjustable linear voltage regulator, the DC power supply, and power load to reproduce VPV $=(T, G, I P V)$ data.



Figure-4. I-V and PV Curve.

The current-voltage $(\mathrm{I}-\mathrm{V})$ and power voltage $(\mathrm{P}-\mathrm{V})$ curves combined are given in Figure 4.MPP is the point where maximum power $\left(\mathrm{P}_{\max }\right)$ is extracted from PV module with voltage as $\mathrm{V}_{\mathrm{mp}}$ and current as $\mathrm{I}_{\mathrm{mp}}$. The $\mathrm{I}-\mathrm{V}$ graph provides information that helps in designing a solar system so that it can work near to its MPP (Abdourraziq, Abdourraziq, Maaroufi, Tlemcani, \& Darab, 2017; Patel \& Rana, 2016).

\subsection{Use of Simulation Software}

This soft panel is applicable for Silov Solution Solar PV Emulator SPVEoo1. SPVEoo1 has 1KW Solar PV Emulator. When using the software, the programmable SPVE0o1 and PC must be connected via a USB cable for command's transmission. The soft panel is designed to program SPVEoo1 as a Solar Panel, and it monitors the output of Solar PV Emulator. When the input parameters are set, the screen will show the output waveform to preview I-V and P-V characteristics of a Solar PV cell or Solar PV Panels before sending out the set voltage and current to the Power Supply.

\section{FUNCTIONING OF AN EMULATOR}

The solar PV emulator is a programmable device designed to emulate an actual solar panel. It comprises of three key elements: - PV Model Implementation, Control Strategy and power stage control (Ebrahim et al., 2015) as shown in Figure 5. The Primary agenda of the PV model implementation is to possess the data in all operating conditions derived from the PV Emulator which imitates the real photovoltaic cell. It generates the characteristics of PV panels. It has three inputs: - Irradiance $(\mathrm{G})$, Temperature (T), measured PV panel current or voltage depending on control type used for the power convertor (voltage controlled or current controlled). The Control Strategy is the level between PV model and power converter. It decides the juncture between load characteristics and PV emulator characteristics (Mallal, El Bahir, \& Hassboun, 2019). The control stage is implemented to lead the measured current or voltage as close as possible to reference current or voltage $\left(\mathrm{I}_{\text {ref }}\right.$ or $\left.\mathrm{V}_{\text {ref }}\right)$. Power convertor can be of three types based on PV emulator purpose: linear regulator (Moussa et al., 2019) programmable DC power supply (Ayop \& Tan, 2017) and switching mode power supply (SMPS) (Ickilli, Can, \& Parlak, 2012). 


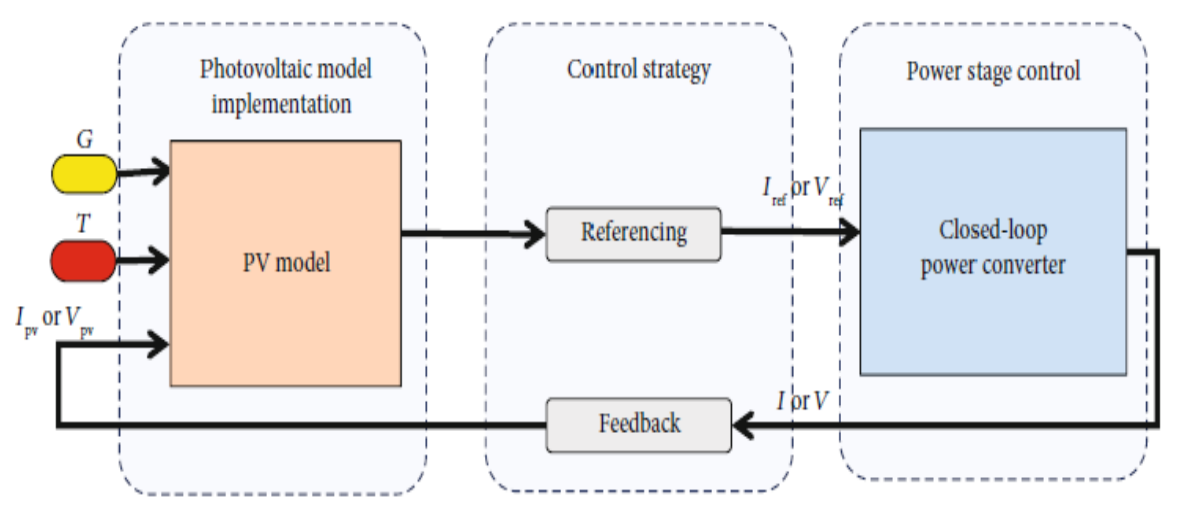

Figure-5. General PV emulator architecture.

\section{EXPERIMENTAL RESULTS}

The experimental setup of Figure 1 is shown in Figure 6 below

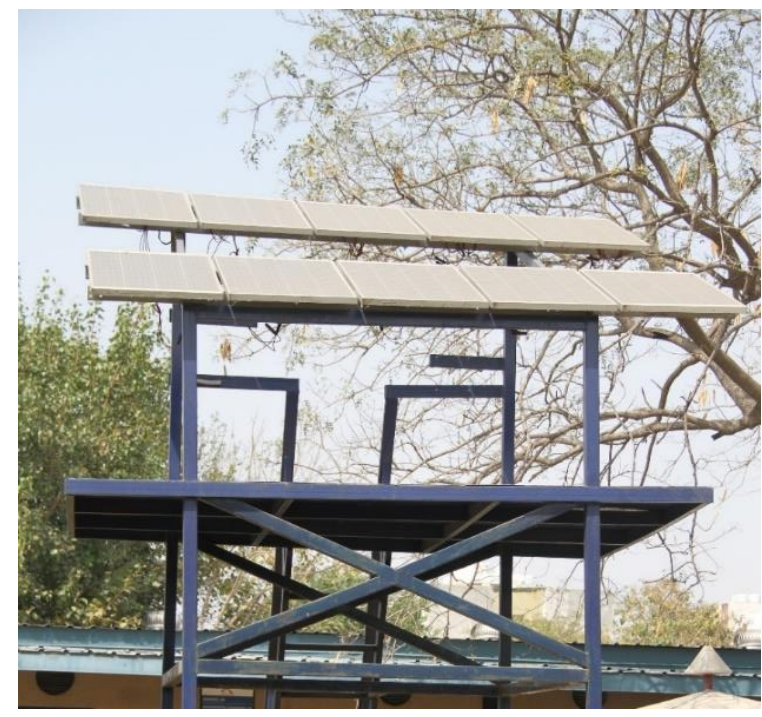

Figure-6(a). Solar Panel of $1 \mathrm{~kW}$ capacity.

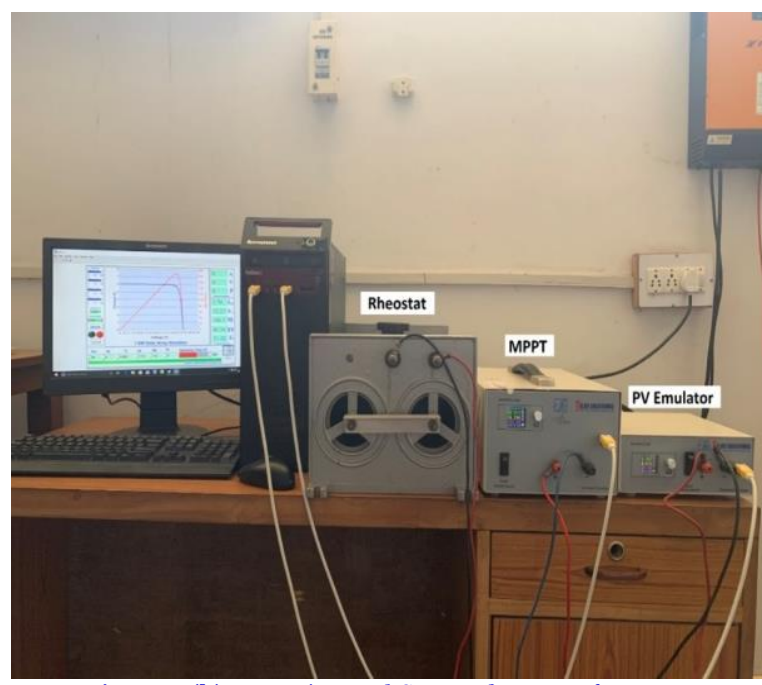

Figure-6(b). Experimental Setup of proposed system.

The Emulator as shown in Figure 6 (b) is connected to the controller through PC which will take control signal from the controller and give the feedback signal to the controller for appropriate action. The output (display 
of PC) panel have irradiance settings of four panels, temperature settings and the value of effect of variation of irradiance, temperature can be measured in terms of current and voltage at Max power, maximum power extracted, fill factor and percentage efficiency.

\section{(a) Effect of Temperature Variations:}

The temperature of the panels is varied from o degrees to 50 degrees in a step of 25 each i.e. $0^{\circ}, 25^{\circ}$ and $50^{\circ}$ keeping irradiance constant at STC and corresponding I-V and P-V curves obtained are shown in Figures 7 (a) and 7 (b). Table 1 shows the corresponding calculated parameters for these variations in temperature.

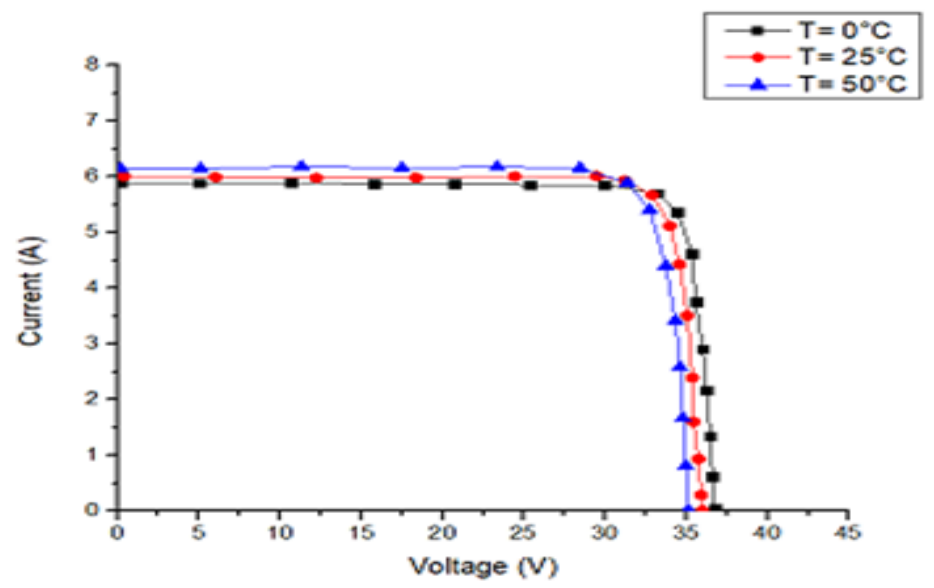

Figure-7(a). I-V curve for temperature variations.

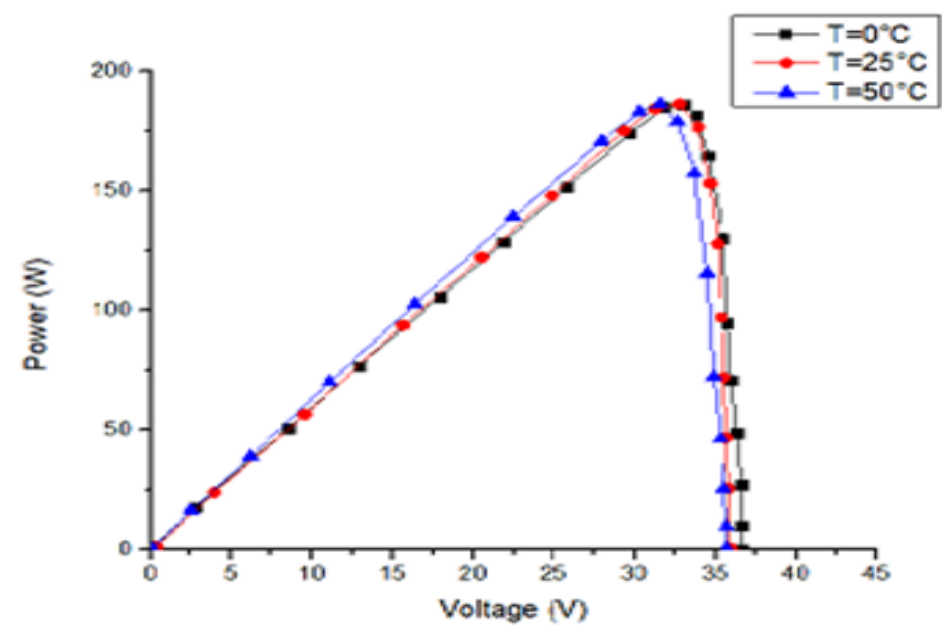

Figure-7(b). P-V curve for temperature variations.

Table-1. Calculated Parameters for temperature variation.

\begin{tabular}{l|c|c|c}
\hline Calculated Parameters & Values at $\mathbf{T}=\mathbf{0}^{\circ} \mathbf{C}$ & Values at $\mathbf{T}=\mathbf{2 5}{ }^{\circ} \mathbf{C}$ & Values at $\mathbf{T}=\mathbf{5 0} \mathbf{~}^{\circ} \mathbf{C}$ \\
\hline Current at max. power, Impp(A) & 5.66 & 5.79 & 5.91 \\
\hline Voltage at max. power, Vmpp(V) & 32.99 & 32.22 & 31.45 \\
\hline Open circuit voltage, Voc(V) & 37 & 36 & 35 \\
\hline Short Circuit current Isc(A) & 5.8 & 6 & 6.2 \\
\hline Maximum power, P(W) & 186.8 & 186.5 & 186 \\
\hline Fill factor, FF & 87.36 & 86.36 & 85.36 \\
\hline Efficiency (\%) & 51.9 & 51.82 & 51.66 \\
\hline
\end{tabular}

The graphs and table given above shows that as the temperature increases, Impp and Isc increases, Vmpp and Voc decreases resulting in decrease in maximum power with increase in temperature. The results also show that 
with the increase in temperature, fill factor and efficiency of generating power also decreases.

(b) Effect of Irradiance Variations

Keeping the temperature constant at STC, the irradiance is varied with values of $1000 \mathrm{~W} / \mathrm{m}^{2}, 650 \mathrm{~W} / \mathrm{m}^{2}$ and $500 \mathrm{~W} / \mathrm{m}^{2}$ and results as obtained are shown in Figures $8(\mathrm{a})$ and Figure 8 (b) in terms of I-V and P-V curve and Table 2 showing the corresponding calculated parameters.

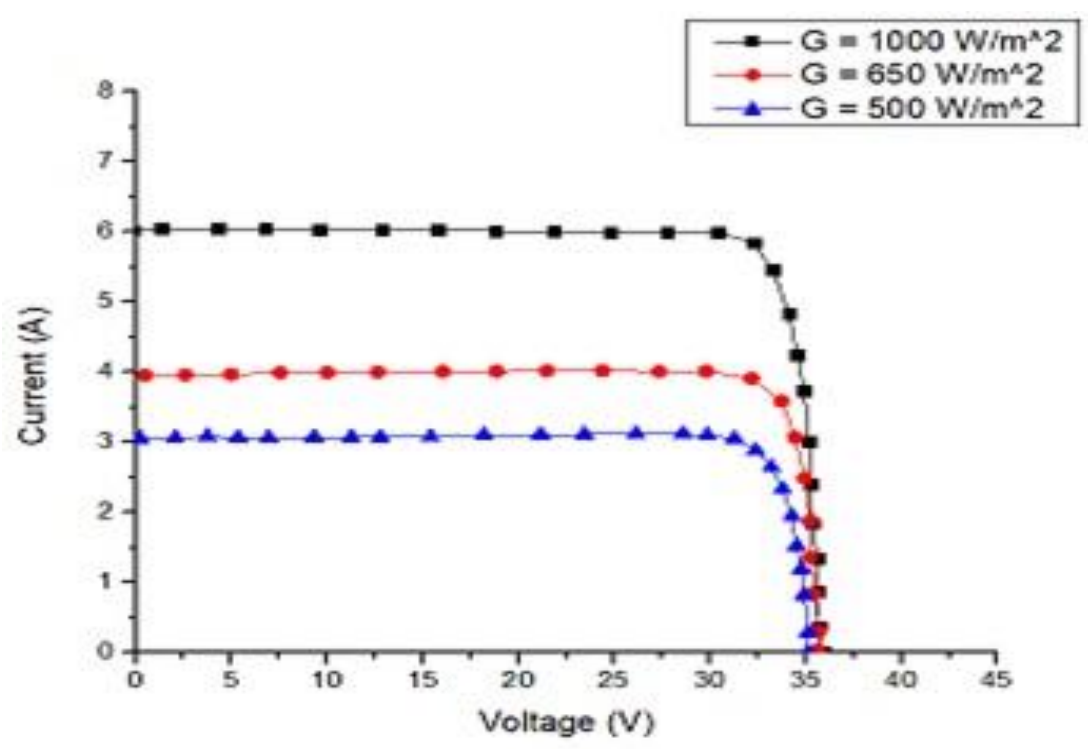

Figure-8(a). I-V curve for irradiance variations.

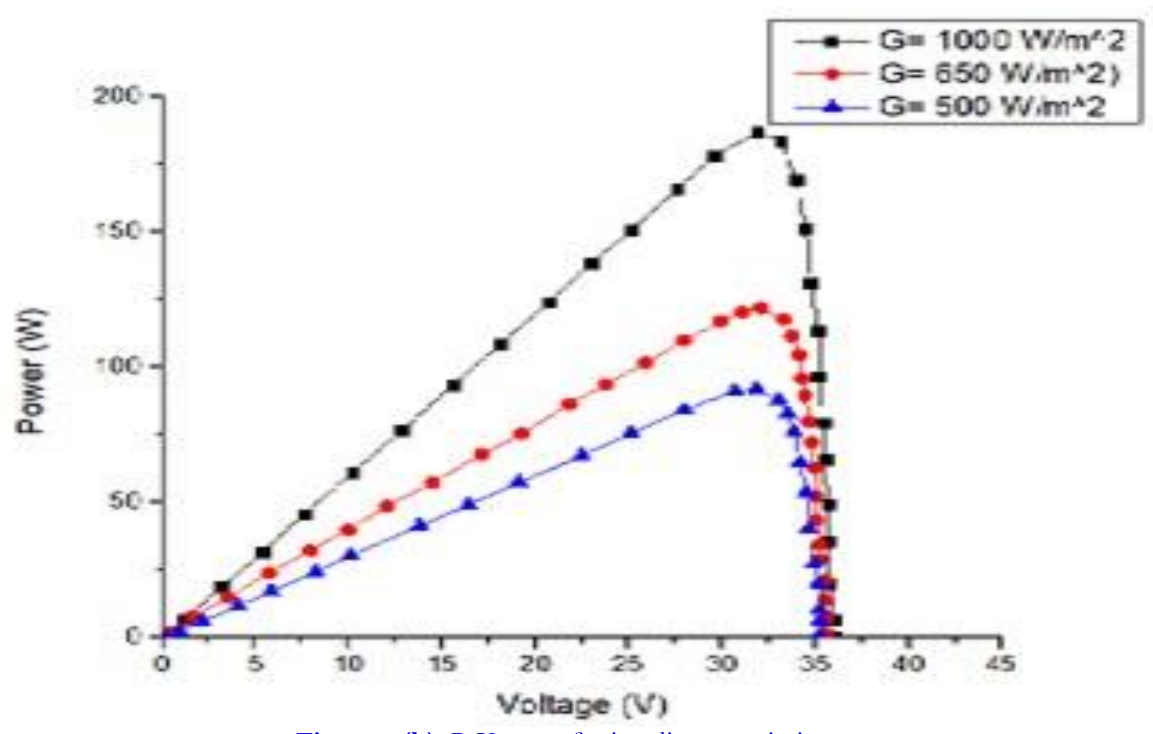

Figure-8(b). P-V curve for irradiance variations.

Table-2. Calculated Parameters for Irradiance variation.

\begin{tabular}{|c|c|c|c|}
\hline Calculated Parameters & $\begin{array}{c}\text { Values at } \\
\mathrm{G}=500 \mathrm{~W} / \mathrm{m}^{2}\end{array}$ & $\begin{array}{c}\text { Values at } \\
\mathrm{G}=650 \mathrm{~W} / \mathrm{m}^{2}\end{array}$ & $\begin{array}{c}\text { Values at } \\
\mathrm{G}=1000 \mathrm{~W} / \mathrm{m}^{2}\end{array}$ \\
\hline Current at max. power-Impp(A) & 2.92 & 3.78 & 5.79 \\
\hline Voltage at max. power-Vmpp(V) & 31.48 & 31.76 & 32.22 \\
\hline Open circuit voltage $\operatorname{VOC}(\mathrm{V})$ & 35 & 35.6 & 35.7 \\
\hline Short Circuit current Isc (A) & 3 & 4 & 6 \\
\hline Maximum power-Mp (W) & 91.96 & 120.3 & 186.5 \\
\hline Fill factor-FF & 85.99 & 86.14 & 86.36 \\
\hline Efficiency (\%) & 50.8 & 51.03 & 51.82 \\
\hline
\end{tabular}


The graphs and table given above shows that as the irradiance increases, Impp, Isc, Vmpp, Voc, Mp, Fill-factor and efficiency all increases however the increase is current is very high as compared to increase in voltages. The variation in currents is nearly double when irradiance doubles resulting in nearly doubling the maximum power extracted from the panels. Thus, by enhancing irradiance the maximum power extracted from the panels improves drastically along with some improvement in efficiency.

\section{(c) Effect of Partial Shading}

Partial shading is the concept of shading effect on few PV panels resulting in difference in irradiance received by these shaded panels as compared to non-shaded panels. The software used in the proposed model have the restriction of irradiance of first panel $\left(\mathrm{G}_{1}\right)>$ irradiance of second panel $\left(\mathrm{G}_{2}\right)>$ irradiance of third panel (G3)>irradiance of fourth panel (G4). Figure 9 (a), Figure 9(b), Figure 9(c) and Figure 9 (d) shows the I-V and P-V curve for the various partial shading conditions of the four panel and Table 3 and Table 4 shows the corresponding calculated parameters.

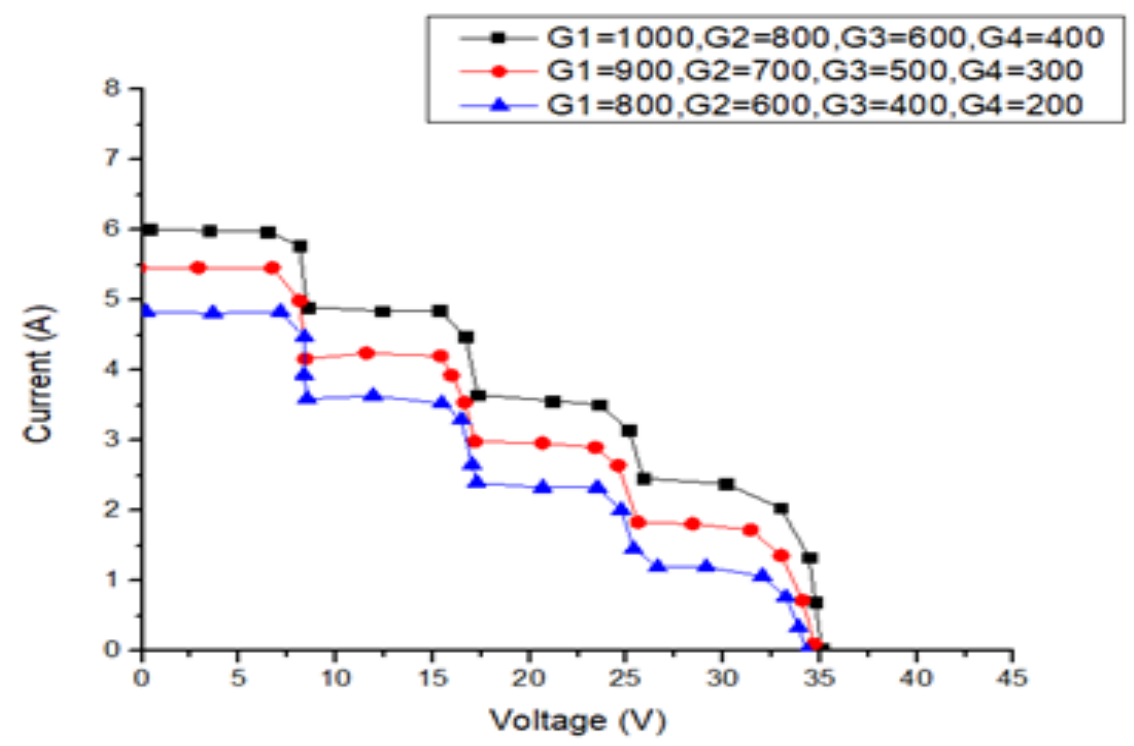

Figure-9(a). I-V curve for partial shadingvariations.

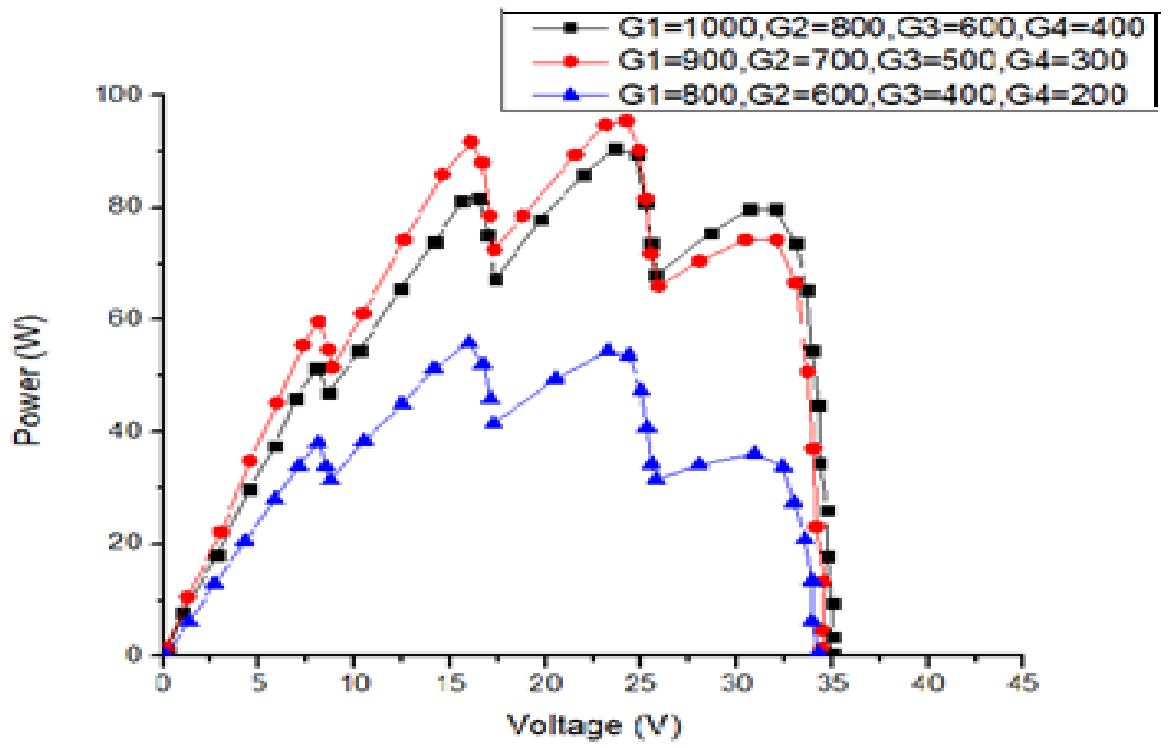

Figure-9(b). P-V curve for partial shading variations. 
Table-3. Calculated Parameters for partial shading variations.

\begin{tabular}{|c|c|c|c|}
\hline Calculated Parameters & $\begin{array}{c}\text { Values at } \\
\text { G1 }=1000 \mathrm{~W} / \mathrm{m}^{2} \\
\text { G2 }=800 \mathrm{~W} / \mathrm{m}^{2} \\
\text { G3 }=600 \\
\mathrm{~W} / \mathrm{m}^{2} \mathrm{G} 4=400 \mathrm{~W} / \mathrm{m}^{2}\end{array}$ & $\begin{array}{c}\text { Values at } \\
\text { G1 }=900 \\
\mathrm{~W} / \mathrm{m}^{2} \mathrm{G} 2=700 \mathrm{~W} / \mathrm{m}^{2} \\
\text { G3 }=500 \\
\mathrm{~W} / \mathrm{m}^{2} \mathrm{G} 4=300 \mathrm{~W} / \mathrm{m}^{2}\end{array}$ & $\begin{array}{c}\text { Values at } \\
\text { G1 }=800 \mathrm{~W} / \mathrm{m}^{2} \mathrm{G} 2=600 \\
\mathrm{~W} / \mathrm{m}^{2} \\
\mathrm{G} 3=400 \mathrm{~W} / \mathrm{m}^{2} \mathrm{G} 4=200 \\
\mathrm{~W} / \mathrm{m}^{2}\end{array}$ \\
\hline $\begin{array}{ll}\text { Current at max. power- } \\
\operatorname{Impp}(\mathrm{A})\end{array}$ & 3.454 & 2.854 & 3.509 \\
\hline $\begin{array}{l}\text { Voltage at max. power- } \\
\operatorname{Vmpp}(\mathrm{V})\end{array}$ & 23.75 & 23.59 & 15.84 \\
\hline Maximum power-Mp(W) & 82.03 & 67.34 & 55.59 \\
\hline $\begin{array}{lll}\text { Open } & \text { circuit } & \text { voltage } \\
\text { VOC }(V) & & \\
\end{array}$ & 35 & 34.9 & 34.8 \\
\hline $\begin{array}{l}\text { Short Circuit current Isc } \\
\text { (A) }\end{array}$ & 6 & 5.5 & 4.9 \\
\hline Fill factor-FF & 39.08 & 35.79 & 33.41 \\
\hline Efficiency (\%) & 32.44 & 31.17 & 30.49 \\
\hline
\end{tabular}

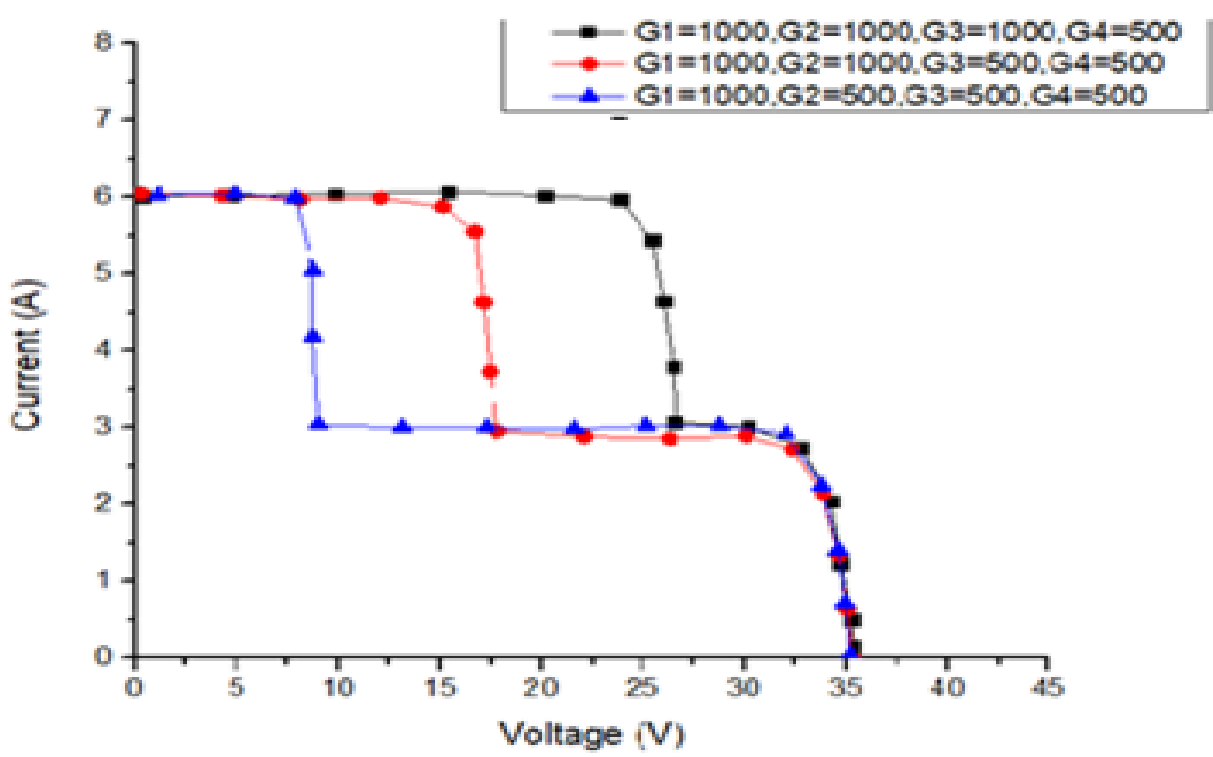

Figure-9(c). I-V curve for partial shading variations.

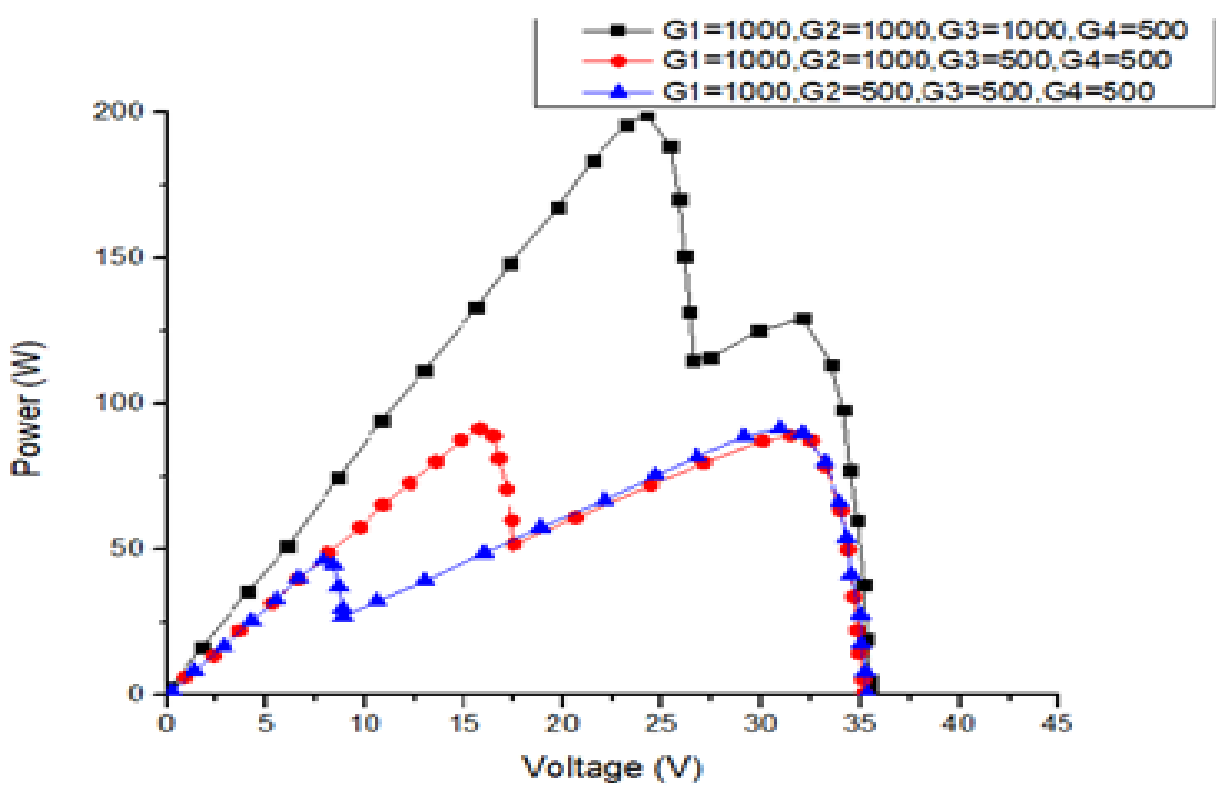

Figure-9(d). P-V curve for partial shading variations. 
Table-4. Calculated Parameters for partial shading variation.

\begin{tabular}{|c|c|c|c|}
\hline Calculated Parameters & $\begin{array}{c}\text { Values at } \\
\text { G1 }=1000 \mathrm{~W} / \mathrm{m}^{2} \\
\mathrm{G} 2=1000 \mathrm{~W} / \mathrm{m}^{2} \\
\mathrm{G} 3=1000 \\
\mathrm{~W} / \mathrm{m}^{2} \mathbf{G} 4=500 \mathrm{~W} / \mathrm{m}^{2} \\
\end{array}$ & $\begin{aligned} \text { Values at } & \\
\text { G1 } & =1000 \\
\mathrm{~W} / \mathrm{m}^{2} \mathrm{G} 2 & =1000 \mathrm{~W} / \mathrm{m}^{2} \\
\mathrm{G} 3 & =500 \\
\mathrm{~W} / \mathrm{m}^{2} \mathrm{G} 4 & =500 \mathrm{~W} / \mathrm{m}^{2}\end{aligned}$ & $\begin{aligned} & \text { Values at } \\
& \text { G1 }=1000 \\
& \mathrm{~W} / \mathrm{m}^{2} \mathbf{G} 2=500 \mathrm{~W} / \mathrm{m}^{2} \\
& \mathbf{G} 3=500 \\
& \mathrm{~W} / \mathrm{m}^{2} \mathbf{G} 4=500 \mathrm{~W} / \mathrm{m}^{2}\end{aligned}$ \\
\hline $\begin{array}{l}\text { Current at } \max \text { power- } \\
\text { Impp(A) }\end{array}$ & 5.79 & 5.721 & 2.854 \\
\hline $\begin{array}{llll}\text { Voltage at max. } & \text { power- } \\
\text { Vmpp(V) } & & & \\
\end{array}$ & 24.16 & 16.1 & 31.46 \\
\hline Maximum power-Mp(W) & 139.9 & 92.12 & 89.79 \\
\hline Open circuit voltage $\mathrm{VOC}(\mathrm{V})$ & 35 & 35 & 35 \\
\hline Short Circuit current Isc(A) & 6 & 6 & 6 \\
\hline Fill factor-FF & 66.21 & 43.6 & 42.49 \\
\hline Efficiency (\%) & 44.64 & 34.39 & 40.09 \\
\hline
\end{tabular}

It is clear from Figure 9 and Table 3,4 that due to partial shading, Maximum power extracted from the panels reduces drastically leading to decrease in fill factor and efficiency.

\section{(d) Comparison of Parameters with and Without Partial Shading Condition}

Table 5 compares the effect of partial shading of only one panel out of four with respect to all non-shaded panels. It is clear from the Table that the power extracted reduces drastically due to partial shading condition thereby reducing the fill factor and overall efficiency of the panels.

Table-5. Comparison of Parameters with and without partial shading (only one panel is partial shaded).

\begin{tabular}{|c|c|c|}
\hline Calculated Parameters & $\begin{array}{c}\text { Values at } \mathrm{G} \\
\text { (i.e. } \mathrm{G} 1=\mathrm{G}_{2}=\mathrm{G} 3=\mathrm{G} 4=1000 \\
\left.\mathrm{~W} / \mathrm{m}^{2}\right)\end{array}$ & $\begin{array}{c}\text { Values at } \\
\text { G1 }=1000 \mathrm{~W} / \mathrm{m}^{2} \mathrm{G} 2=1000 \mathrm{~W} / \mathrm{m}^{2} \\
\text { G3 }=1000 \mathrm{~W} / \mathrm{m}^{2} \mathrm{G} 4=500 \mathrm{~W} / \mathrm{m}^{2}\end{array}$ \\
\hline Current at max. power-Impp(A) & 5.79 & 5.79 \\
\hline Voltage at max. power-Vmpp(V) & 32.22 & 24.16 \\
\hline Open circuit voltage $\mathrm{VOC}(\mathrm{V})$ & 35.7 & 35 \\
\hline Short Circuit current Isc (A) & 6 & 6 \\
\hline Maximum power-Mp(W) & 186.5 & 139.9 \\
\hline Fill factor-FF & 86.36 & 66.21 \\
\hline Efficiency (\%) & 51.82 & 44.64 \\
\hline
\end{tabular}

\section{CONCLUSION}

This paper presented an insight of the PV emulator and its ability to produce I-V and P-V characteristics like the actual PV panels under different environmental conditions. This will be helpful to replicate actual solar panels from different manufacturers by providing information about the effect of variations due to the temperature, irradiance, and partial shading on overall performance. A hardware experimental set up is formulated in the research lab wherein an emulator is connected to controller and software for analysis purposes. The result hence obtained is summarized as below:

1. As the temperature increases, Impp and Isc increases, Vmpp and Voc decreases, resulting in decrease in maximum power extracted from the panels and decrease in efficiency.

2. As the irradiance increases, Impp, Isc, Vmpp, Voc, Mp, Fill-factor and efficiency increases, however the increase in current is very high as compared to increase in voltage, leading to very high increase in maximum power extracted from the panels.

3. Due to partial shading, maximum power extracted from the panels reduces drastically, leading to decrease in efficiency.

The obtained results show the ability of the photovoltaic emulator to replicate the results obtained from actual 
PV panels. Along with this, it will be worthy to share that emulator requires much less space than a photovoltaic system. The PV emulator also allows the modules to be characterized under known conditions and can be translated for other conditions, i.e. if it is cloudy and the short-circuit current is lower than expected, the converted values can properly indicate expected short-circuit current, etc. thereby helpful in obtaining various research related parameters for performance analysis of modelled PV Panel. The PV emulator can further be used to test various MPPT algorithms with or without load safely for comparison purposes before hardware implementations.

Funding: The findings are obtained from the project funded by Department of Science and Technology (DST), Government of India. The sanction letter number is ET-92/2017 (G).

Competing Interests: The author declares that there are no conflicts of interests regarding the publication of this paper.

Acknowledgement: Author acknowledges Silov Solutions Pvt. Ltd. Incubated in IIT Delhi,

India for supporting her with the equipments to conduct the experimental work in our lab.

\section{REFERENCES}

Abdourraziq, M. A., Abdourraziq, S., Maaroufi, M., Tlemcani, M., \& Darab, C. (2017). Experimental results of photovoltaic emulator systems. Paper presented at the 2017 International Conference on Electromechanical and Power Systems (SIELMEN) IEEE.

Al-Shetwi, A. Q., Sujod, M. Z., \& Ramli, N. L. (2015). A review of the fault ride through requirements in different grid codes concerning penetration of pv system to the electric power network. ARPN Journal of Engineering and Applied Sciences, 10(21), 9906-9912.

Ayop, R., \& Tan, C. W. (2017). A comprehensive review on photovoltaic emulator. Renewable and Sustainable Energy Reviews, 80, 430-452. Available at: https://doi.org/10.1016/j.rser.2017.05.217.

Babu, T. S., Ram, J. P., Sangeetha, K., Laudani, A., \& Rajasekar, N. (2016). Parameter extraction of two diode solar PV model using fireworks algorithm. Solar Energy, 140, 265-276. Available at: https://doi.org/10.1016/j.solener.2016.10.044.

Chiang, S.-J., Chang, K. T., \& Yen, C. Y. (1998). Residential photovoltaic energy storage system. IEEE Transactions on Industrial Electronics, 45(3), 385-394. Available at: https://doi.org/10.1109/41.678996.

Ebrahim, A. F., Ahmed, S., Elmasry, S., \& Mohammed, O. A. (2015). Implementation of a PV emulator using programmable DC power supply. Paper presented at the Southeast Conference 2015.

Ickilli, D., Can, H., \& Parlak, K. S. (2012). Development of a FPGA-based photovoltaic panel emulator based on a DC/DC converter. Paper presented at the 2012 38th IEEE Photovoltaic Specialists Conference. IEEE.

Mallal, Y., El Bahir, L., \& Hassboun, T. (2019). High-performance emulator for fixed photovoltaic panels. International Journal of Photoenergy, 1-11. Available at: https://doi.org/10.1155/2019/3951841.

Messaoudi, H., Bennani, A. B. A., Bellaaj, N. M., \& Orabi, M. (2016). â€ design and implementation of a solar PV emulatorâ€ $€^{\mathrm{TM}}$. Paper presented at the First International Refrigeration Energy and Environment Colloquium (IREEC1).

Moussa, I., Khedher, A., \& Bouallegue, A. (2019). Design of a low-cost PV emulator applied for PVECS. Electronics, 8(2), 232. Available at: https://doi.org/10.3390/electronics8020232.

Nishioka, K., Sakitani, N., Uraoka, Y., \& Fuyuki, T. (2007). Analysis of multicrystalline silicon solar cells by modified 3-diode equivalent circuit model taking leakage current through periphery into consideration. Solar Energy Materials and Solar Cells, 91(13), 1222-1227. Available at: https://doi.org/10.1016/j.solmat.2007.04.009.

Patel, B. D., \& Rana, A. (2016). A pole-placement approach for buck converter based PV array emulator. Paper presented at the 2016 IEEE 1st International Conference on Power Electronics, Intelligent Control and Energy Systems (ICPEICES), IEEE, 2016.

Shahabuddin, M., Riyaz, A., Asim, M., Shadab, M. M., Sarwar, A., \& Anees, A. (2018). Performance based analysis of solar PV emulators: A review. Paper presented at the 2018 International Conference on Computational and Characterization Techniques in Engineering \& Sciences (CCTES), IEEE, 2018. 
Vagapov, Y., \& Alecksey, A. (2016). Low-cost photovoltaic emulator for instructional laboratories. Paper presented at the 201651 st International Universities Power Engineering Conference (UPEC), IEEE, 2016.

Vlad, C., Păduraru, R., Epure, S., Barbu, M., Dache, C., \& Lungu, C. V. (2017). PV emulation under commercially available programmable DC voltage source. Paper presented at the 2017 5th International Symposium on Electrical and Electronics Engineering (ISEEE), IEEE, 2017.

Zhou, Z., Holland, P., \& Igic, P. (2014). MPPT algorithm test on a photovoltaic emulating system constructed by a DC power supply and an indoor solar panel. Energy Conversion and Management, 85, 460-469. Available at: https://doi.org/10.1016/j.enconman.2014.06.007.

Views and opinions expressed in this article are the views and opinions of the author(s), International Journal of Sustainable Energy and Environmental Research shall not be responsible or answerable for any loss, damage or liability etc. caused in relation to/arising out of the use of the content. 